\title{
KAJIAN KEBIJAKAN TATA USAHA KAYU HUTAN RAKYAT: Studi Kasus di Kabupaten Ciamis, Jawa Barat
}

\section{(Policy Analysis on Wood Administration System of Private Forests: A Case Study at Ciamis District, West Java)}

\author{
Oleh/by: \\ Subarudi ${ }^{1}$
}

\begin{abstract}
Ciamis District is one of the mostpotential private forests in West Java region with its annual log production of 325,000 $\mathrm{m}^{3}$. Although Ciamis has issued the local regulation (Perda) No. 19 Year 2004 regarding the wood administration system, the system has many problems in its implementation. Therefore, an assessment on log supplydemand and wood administration system is needed. The assessment used a focused synthesis method. The results showed that the log demand in Ciamis is (2-4 times) bigher than the recorded log production. The wood shortage demands a wood industry restructuring policy. The misuses of wood administration system were: (i) forestry extension officers tend to work as wood administrators, (ii) the field checking of trees being felled has sometime never been done, (iii) heads of village signed the wood origin document without field inspection, (iv) wood administration document is difficult and bureancratic to obtain. To overcome the problems there were four strategies should be conducted, namely: (i) create a same perception on wood legal document (SKSSH), (ii) design the wood administration system in accordance with its forest types, (iii) wood administration system applied in private forests should be simple, easy and low cost, and (iv) revitalize the role and function of the extension workers.
\end{abstract}

Key words: Wood administration system, private forestpolicy, log supply-demand

\begin{abstract}
ABSTRAK
Kabupaten Ciamis merupakan salah satu kabupaten potensial untuk pengembangan hutan rakyat di Jawa Barat dengan produksi kayu tahunannya sebesar $325.000 \mathrm{~m}^{3}$. Meskipun Ciamis telah mengeluarkan Peraturan daerah (Perda) No. 19 Tahun 2004 berkaitan dengan sistem tata usaha kayu (TUK), sistem TUK tersebut masih memiliki kendala dalam penerapannya di lapangan. Oleh karena itu kajian tentang pasokan dan kebutuhan kayu serta sistem TUK nya sangat dibutuhkan. Kajian ini menggunakan sebuah metoda sintesa terfokus (a focused synthesis method). Hasil kajian menunjukkan bahwa kebutuhan kayu bulat di Ciamis sebesar 2 - 4 kali lipat dari total produksi kayu bulat yang tercacat. Kelangkaan bahan baku kayu ini menuntut sebuah kebijakan restrukturisasi industri kayu di Ciamis. Masalah-masalah yang timbul dalam penerapan TUK adalah: (i) penyuluh kehutanan yang bekerja rangkap sebagai perantara pengurusan dokumen kayu, (ii) pengecekan di lapangan kadangkala tidak dilakukan, (iii) kepala desa hanya menandatangani surat asal usul kayu tanpa verifikasi di lapangan, (iv) pengurusan dokumen masih sulit dan biroktatis.
\end{abstract}

${ }^{1)}$ Team Leader ITTO PD 271/04 Rev. 3 (F), Ciamis 


\section{J umal AnalisisKedijakanKehutanan Vo. 3No 2, Juni 2006: 109- 123}

Untuk mengatasi masalah tersebut ada 4 (empat) strategi yang meliputi: (1) penyamaan persepsi tentang SKSHH, (2) sistem TUK sesuai dengan asal usul kayu, (3) sistem TUK yang mudah dan murah, dan (4) revitalisasi peran dan fungsi penyuluh.

Kata kunci: Tata usaha kayu, kebijakan hutan rakyat, kebutuhan dan pasokan kayu

\section{PENDAHULUAN}

Produksi kayu dari hutan rakyat seluas 28.000 ha tahun 2005 di kabupaten Ciamis mencapai $325.000 \mathrm{~m}^{3}$. Jumlah produksi kayu rakyat tersebut enam kali lipat dari produksi kayu dari hutan negara $\left(55.000 \mathrm{~m}^{3}\right)$ dengan luasan sekitar 30.000 ha yang dikelola Perum Perhutani (Kompas, 07/07/2006).

Kabupaten Ciamis sejak tahun 2004 melalui Perda No. 19 tahun 2004 tentang Produksi dan Peredaran Kayu Rakyat telah mendelegasikan ijin tebangan kayu rakyat kepada kepala desa dengan menerbitkan Surat Keterangan Asal Usul Kayu (SKAUK) yang menunjukkan bahwa kayu yang ditebang berasal dari lahan milik perseorangan yang telah mengajukan permohonan ijin tersebut.

Dilain pihak keluarnya Peraturan Menteri Kehutanan Nomor 51 Tahun 2006 tentang Penggunaan Surat Keterangan Asal Usul (SKAU) untuk pengangkutan hasil hutan kayu dari hutan hak merupakan suatu kebijakan tata usaha kayu (TUK) yang baru bagi kabupaten-kabupaten lainnya dan rencananya akan diterapkan mulai Bulan Januari 2007.

Berkaitan dengan hal tersebut dan dalam rangka sosialisasi Permenhut No. 51/2006, maka informasi sekitar pelaksanaan TUK hutan rakyat di Kabupaten Ciamis sangat diperlukan untuk menarik pelajaran (lesson learned) dan pengalamannya dalam menerapkan SKAUK untuk penebangan dan pengurusan dokumen pengangkutan kayu hutan rakyat.

Sistem TUK di Kabupaten Ciamis ini sangat menarik untuk dikaji lebih lanjut jika dikaitkan dengan keberadaan unit Sentra Industri merupakan perpajangan tangan dari Balai Pengawasan Peredaran Kayu (BP2K) di Cirebon. BP2K merupakan Unit Pelaksana Teknis Daerah (UPTD) Dinas Kehutanan Provinsi yang tugas pokoknya mengawasi lalu lintas peredaran kayu olahan dan kayu bulat di provinsi Jawa Barat. Hal ini membawa kerancuan dan dualisme dalam pengurusan dokumen kayu, dimana Dinas Kehutanan Ciamis bertanggung jawab terhadap dokumen kayu dari hutan ke Industri, namun setelah menjadi produk kayu olahan semua dokumennya ditangani oleh unit Sentra Industri yang berada di setiap kabupaten di Jawa Barat.

Oleh karena itu kajian kebijakan tata usaha kayu (TUK) di kabupaten Ciamis menjadi penting dan sangat diperlukan sebagai upaya untuk sosialisasi penerapan SKAU dan juga untuk memperbaiki dan menyempurnakan sistem TUK yang ada. Kajian TUK di Kabupaten Ciamis bertujuan: (i) mengevaluasi kebenaran data produksi kayu di Ciamis, (ii) menganalis pasokan dan kebutuhan kayu di Ciamis, (iii) mengevaluasi sistem TUK nya, dan (iv) merumuskan kebijakan-kebijakan sistem TUK yang tepat untuk mendukung pengelolaan hutan rakyat lestari. 


\section{METODE PENELITIAN}

\section{A. Lokasi dan Waktu Penelitian}

Penelitian tentang kebijakan tata usaha kayu di Kabupaten Ciamis dilaksanakan secara Desk Studi terhadap beberapa hasil penelitian yang terkait dengan topik penelitian.

Kajian sistem TUK ini dilakukan di kabupaten Ciamis karena beberapa alasan, diantaranya: (i) Kabupaten Ciamis telah mengeluarkan perda No. 19 Tahun 2004 tentang produksi dan peredaran kayu rakyat yang mana konsepnya sudah cukup baik, namun pelaksanaannya di lapangan masih jauh dari yang diharapkan, (ii) produksi kayunya paling besar di seluruh Jawa Barat, (iii) kabupaten Ciamis mempunyai visi menjadi sentra pengelolaan hutan rakyat lestari pada tahun 2009, (iv) Industri kayu penggergajian yang dimiliki sekitar 426 unit, dan (v) sebagian besar kayu produksi Kabupaten Ciamis diperjual belikan lintas provinsi DKI, Banten, Jawa Tengah, dan Jawa Timur.

Penelitian ini dilaksanakan selama 4 (empat) bulan dari mulai Bulan April-Juli 2006. Penekanan khusus dilakukan pada wilayah kecamatan-kecamatan di Kabupaten Ciamis yang dikenal sebagai penghasil kayu rakyat.

\section{B. Pengumpulan Data}

Data yang dikumpulkan terdiri dari data primer dan data sekunder. Data primer diperoleh dari hasil wawancara dengan petani, pedagang pengumpul, industri pengolah kayu, dan pihak-pihak yang terlibat dalam pemasaran kayu bulat dan kayu olahan. Sedangkan data sekunder dikumpulkan dari berbagai instansi terkait diantaranya; Dinas Kehutanan propinsi dan kabupaten, Dinas industri dan perdagangan, Pemerintah daerah, dan pelaku bisnis perkayuan serta Asosiasi Pengusaha Kayu Rakyat (APKR) Ciamis.

\section{Analis Data}

Kajian kebijakan yang digunakan dalam penelitian ini menggunakan metode sintesa terfokus (a focused synthesis method). Burton (1979) dalam Danim (2000) menyatakan bahwa metode sintesa dapat digunakan untuk: (i) mengkaji literatur yang tersedia dan berkaitan dengan persoalan utama atau fokus penelitian; (ii) tukar menukar pengalaman penelitian di lapangan; dan (iii) mendiskusikan dengan orang-orang yang berkompeten di bidangnya sebagaimana diilustrasikan dalam Gambar 1. 

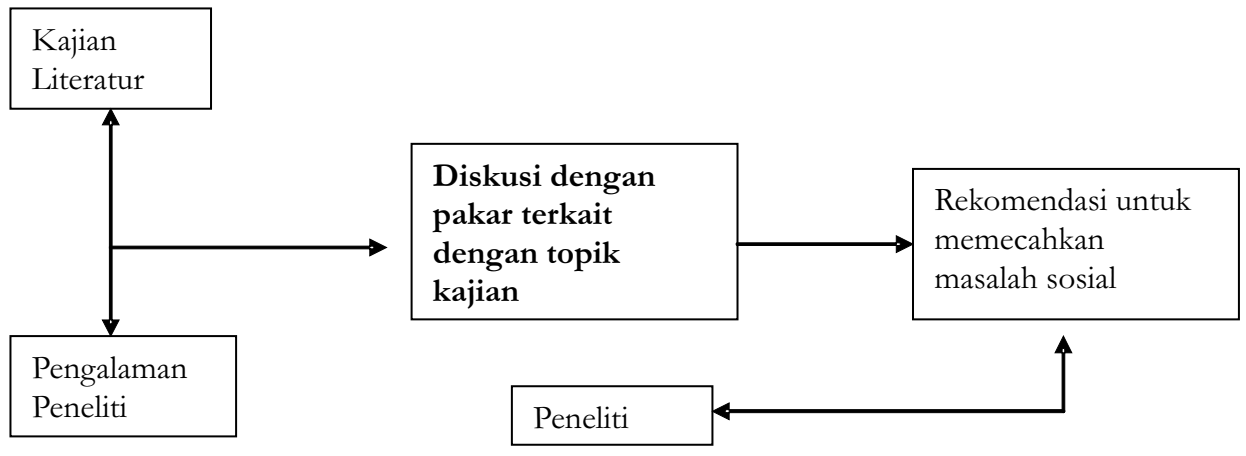

Gambar1. Sebuah mekanisme kerja dari metode sintesa terfokus

Figure 1. A working mechnism from the focused synthesis method

Di lain pihak analisa pasokan kayu dihitung dengan rumus:

$$
P=S K p \times 1 / R
$$

Dimana: $\mathrm{P}=$ Pasokan kayu;

$\mathrm{S}=$ Jumlah unit penggergajian;

$\mathrm{Kp}=$ Kapasitas produksi per unit penggergajian; dan

$\mathrm{R}=$ Rendemen kayu gergajian (rasio antara output dan input dalam unit persen $(\%))$.

\section{HASIL DAN PEMBAHASAN}

\section{A. Validasi Data Produksi Kayu di Ciamis}

Pencantuman produksi kayu rakyat di Ciamis sebesar $325.000 \mathrm{~m}^{3}$ tahun 2005 sebagaimana tercantum dalam Laporan Pertanggung Jawaban (LPJ) Bupati Ciamis tahun 2005 menjadi bahan perdebatan di ruang persidangan DPRD karena produksi kayu yang demikian besar dianggap dilakukan dengan menguras "habis" sumber daya hutan yang ada. Hal ini tentunya akan berdampak kepada kerusakan lingkungan di kabupaten Ciamis dan sekitarnya.

Persoalan besarnya produksi kayu rakyat tahun 2005 memang menarik untuk dikaji lebih lanjut karena di satu pihak produksi kayu yang besar menjadi kebanggaan atau keberhasilan Dinas Kehutanan Ciamis, tapi di lain pihak menjadi keprihatinan anggota DPRD Ciamis.

Sebenarnya kontroversi jumlah tebangan dapat dievaluasi dengan menggunakan prinsip kelestarian hutan yang sederhana, yaitu jumlah pohon yang ditebang sama dengan jumlah pohon yang ditanam. Hal ini merupakan penyederhanan dari konsep ilmu kehutanan bahwa pohon yang ditebang merupakan riap atau laju pertumbuhannya dari 
suatu tegakan sehingga sumber daya hutan (SDH) dikenal sebagai sumber daya alam yang dapat diperbaharui (renewable resources).

Dalam kasus kelestarian SDH di Ciamis dapat dihitung secara cermat dengan melalui konversi dari jumlah kubikasi ke dalam jumlah pohon yang ditebang. Jika asumsi pohon yang ditebang mempunyai rasio 1:5 dalam artian $1 \mathrm{~m}^{3}$ kayu membutuhkan 5 batang pohon dengan ukuran diameter 20-22 cm dan panjang 15 meter, maka jumlah kayu yang ditebang sekitar 1,6 juta batang pohon. Pertanyaan yang muncul tentang kelestarian adalah apakah laju penanaman di Ciamis baik melalui kegiatan Gerhan dan GRLK (gerakan rehabilitasi lahan kritis) sudah sama atau melebihi jumlah pohon yang ditebang tersebut?

Kontroversi tersebut akan terus berlanjut, karena kenyataan yang ada menunjukkan bahwa sistem administrasi kehutanan di Ciamis belum mendukung ke arah pengelolaan hutan rakyat yang lestari di mulai dari tingkat dusun dan desa hingga ke kecamatan-kecamatan. Padahal dalam Perda Kabupaten No. 19/2004, Pasal 2 dinyatakan bahwa "setiap orang/badan usaha yang akan menebang pohon kayu rakyat untuk berbagai kepentingan (jual beli dan dipakai sendiri), wajib melaporkan/ memberitahukan rencana penebangan dan realisasinya kepada kepala desa/kelurahan yang dilengkapi dengan (i) denah lokasi penebangan, (ii) potensi tegakan pohon kayu/ daftar klem kayu, dan (iii) laporan produksi kayu, serta (iv) foto copy tanda bukti pembelian untuk kayu yang diperjual belikan".

Kemungkinan besar data produksi kayu dari hutan rakyat sebanyak $325.000 \mathrm{~m}^{3}$ sudah tercatat karena memang ada UPTD Dinas Kehutanan Ciamis yang menangani khusus penebangan dan penerbitan surat keterangan asal usul kayu (SKAUK) dan surat keterangan sahnya hasil hutan (SKSHH), namun data jumlah pohon yang ditanam masih belum dapat dimonitor dan divalidasi kebenaran datanya.

Sehubungan dengan hal tersebut dalam pertemuan konsultan ITTO dengan para penyuluh dan LSM, tanggal 5 Juli 2005 muncul pertanyaan tentang kehadiran UPTD "penebangan" Dinas Kehutanan Ciamis dan saran untuk ditinjau kembali dalam upaya merestrukturisasi kelembagaan yang ada dan mendukung pencapaian visi "Sentra Pengembangan Hutan Rakyat lestari".

Oleh karena untuk menghindari kontroversi tentang produksi kayu dan jumlah pohon yang ditebang, maka tidak ada pilihan lain bagi Dinas Kehutanan Ciamis untuk memperbaiki sistem administrasi kehutanannya baik di tingkat dusun, desa, dan kecamatan serta mengkaji ulang struktur organisasinya dalam upaya pencapaian visi dan misinya.

\section{B. Analisis Pasokan dan Kebutuhan Kayu}

Analisis pasokan dan kebutuhan kayu ini dilakukan sebagai upaya untuk melihat sejauh mana pasokan kayu dibandingkan dengan jumlah kebutuhannya yang dicerminkan dengan kebutuhan bahan baku kayu untuk industri penggergajian dan industri pengolahan lanjutan (wood working industries).

Cara perhitungan kebutuhan kayu bulat dapat dihitung maju (forward calculation) sebagai berikut: (i) jika data produksi kayu bulat Ciamis sebanyak $325.000 \mathrm{~m}^{3}$ (dianggap benar dan akurat) dengan jumlah 426 unit penggergajian, maka 1 unit penggergajian 


\section{J umal AnalisisKedijakanKehutanan Vo. 3No. 2, J uni 2006: 109- 123}

membutuhkan kayu sebanyak $763 \mathrm{~m}^{3} /$ tahun, (ii) dengan masa operasional unit penggergajian hanya 11 bulan dalam setahun, maka kebutuhan kayu bulat per bulan sekitar $69 \mathrm{~m}^{3}$ atau 3,45 $\mathrm{m}^{3}$ per hari per unit (20 hari kerja per bulan), (iii) dengan menggunakan rendemen rata-rata penggergajian sekitar $60 \%$, maka produk kayu gergajian yang dihasilkan sebanyak $2,07 \mathrm{~m}^{3}$ per hari per 1 unit penggergajian. Sebuah unit penggergajian dengan tingkat produksi sekitar $2,1 \mathrm{~m}^{3} /$ hari dirasakan terlalu rendah produktivitasnya dan dapat dikatakan tidak layak secara teknis dan ekonomis bagi suatu usaha bisnis penggergajian.

Perhitungan lainnya dapat dilakukan secara balik atau mundur (backward calculation). Hasil peninjauan ke beberapa industri penggergajian di Ciamis menunjukkan rata-rata produksi kayu gergajian untuk 1 unit Band Saw mencapai $5-7 \mathrm{~m}^{3} /$ hari dengan rata-rata rendemen $60 \%$ maka kebutuhan kayu sebesar $8-12 \mathrm{~m}^{3} /$ hari/unit penggergajian.

Wawancara dengan operator perusahaan penggergajian di Desa Panumbangan, Kecamatan Panumbangan menuturkan bahwa mereka beroperasi 3 minggu dalam sebulan (1 minggu libur karena operatornya pulang kampung ke Cirebon) dan tidak pernah berhenti karena kekurangan bahan baku. Dengan menggunakan asumsi mereka beroperasi 20 hari dalam sebulan, maka kebutuhan kayu untuk 1 unit industri penggergajian tersebut sebanyak $160-240 \mathrm{~m}^{3} /$ bulan atau sekitar $1.760-2.640 \mathrm{~m}^{3} /$ tahun (setahun dihitung 11 bulan karena umumnya bulan puasa libur satu bulan penuh).

Hasil konfirmasi dan validasi data ke Dinas Perindustrian dan Perdagangan Kabupaten Ciamis menunjukkan bahwa jumlah unit penggergajian kayu sebanyak 426 unit dengan kapasitas produksi setahun sebesar $900-2500 \mathrm{~m}^{3}$ per tahun. Hal ini menunjukkan bahwa perhitungan kapasitas produksi $1.760-2.640 \mathrm{~m}^{3} /$ tahun masih dalam kisaran produksi yang wajar dan sesuai dengan kondisi di lapangan. Jadi total kebutuhan kayu untuk 426 unit penggergajian mencapai 0,75-1,12 juta $\mathrm{m}^{3}$ kayu bulat per tahun. Dalam hal ini, kayu yang sebenarnya ditebang di kabupaten Ciamis 2-4 kali lebih besar dari data yang tercatat $\left(325.000 \mathrm{~m}^{3}\right)$. Dengan kata lain ada peredaran kayu yang tidak tercatat di kabupaten Ciamis sebanyak 425.000-795.000 $\mathrm{m}^{3}$ per tahun.

Dalam hal ini keberadaan industri penggergajian di Ciamis sudah merupakan ancaman bagi kelestarian pengelolaan hutan baik hutan rakyat ataupun hutan negara, sehingga diperlukan kebijakan restrukturisasi industri penggergajian. Apalagi keberadaan unit penggergajian tersebut dapat dikatakan liar (illegal) karena belum memperoleh ijin dari Dinas Kehutanan Provinsi sesuai dengan PP No. 34 Tahun 2002 yang menyebutkan bahwa perijinan industri perkayuan dengan kapasitas produksi diatas 6000 m3 per tahun ditangani oleh Departemen Kehutanan dan kapasitas dibawah 6000 m3 per tahun diberikan oleh Dinas Kehutanan Provinsi.

Penertiban industri tanpa ijin telah dilakukan di Kabupaten Tangerang sesuai dengan Perda Nomor 7 Tahun 2002 tentang Pengaturan, Pembinaan, dan Pengendalian Industri yang merupakan penjabaran dari UU NO. 5 Tahun 1984 tentang Perindustrian. Dengan berbekal Perda tersebut, sebanyak 250 perusahaan mulai skala kecil hingga besar yang tidak mengantongi ijin industri di Kabupaten Tangerang bakal ditertibkan dan 5 (lima) perusahaan sudah diberikan peringatan oleh Dinas Indagkokpar. Jika hal ini dikaitkan dengan Pasal 62 KUHAP tentang Penertiban Perusahaan Tidak Berijin akan dikenai ancaman hukuman sekitar 5 (lima) tahun penjara 
atau denda Rp 5 juta (Seputar Indonesia, 16/06/2006).

Oleh karena itu, kebijakan restrukturisasi industri penggergajian di Kabupaten Ciamis harus menjadi prioritas utama perumusan kebijakan apabila kelestarian hutan dan lingkungan menjadi perhatian semua pihak sehingga Ciamis dapat merealisasikan visi dan misinya menjadi model pengembangan hutan rakyat lestari bagi kabupaten-kabupaten lain di Jawa Barat khususnya dan Pulau Jawa pada umumnya.

\section{Evaluasi Sistem TUK}

Tata Usaha Kayu (TUK) adalah sistem administrasi yang mengatur dan mengarahkan peredaran kayu baik berupa kayu bulat maupun kayu olahan. Sistem TUK ini diberlakukan sama baik dari kayu yang berasal dari hutan alam, hutan tanaman, dan hutan rakyat dengan menggunakan SKSHH. Perda Kabupaten Ciamis No. 19/2004 tentang Sistem Produksi dan Peredaran Kayu Rakyat sebenarnya sudah ideal dalam tataran konseptual, namun dalam tataran pelaksanaannya di lapangan masih menghadapi kendala dan hambatan yang mempengaruhi bagi perkembangan hutan rakyat itu sendiri.

Sebagai contoh dalam Perda No. 19/2004 Pasal 2 Ayat 5-9 dinyatakan bahwa (i) berdasarkan laporan rencana penebangan, kepala desa/kelurahan bersama-sama petugas kehutanan setempat mengadakan pengecekan lapangan; (ii) apabila berdasarkan hasil pengecekan lapangan terjadi kesesuaian antara laporan dengan fisik lapangan, kepala desa/kelurahan menerbitkan SKAUK; (iii) pelaksanaan penebangan baru dapat dilakukan setelah memperoleh SKAUK; dan (iv) semua orang/badan usaha yang telah melakukan penebangan, wajib melaksanakan penanaman kembali.

Penyimpangan pelaksanaan TUK di Ciamis meliputi: (i) peran dan fungsi penyuluh yang berubah, (ii) pengurusan dokumen kayu yang berbiaya tinggi, (iii) marjinalisasi peran desa dalam penerbitan SKAUK, dan (iv) pembinaan dan pengawasan yang belum berjalan.

\section{Peran dan fungsi penyuluh berubah}

Kenyataannya aturan TUK tersebut berbeda di dalam penerapannya, dimana laporan rencana penebangan tidak dibuatkan oleh petugas kehutanan, tetapi oleh PKL (Penyuluh Kehutanan Lapangan) yang merangkap tugas juga sebagai petugas kehutanan. Oknum PKL tersebut juga yang mendatangi dan "meminta" kepala desa/kelurahan untuk menerbitkan dan menandatangani dokumen SKAUK tanpa melakukan pengecekan di lapangan.

Peran PKL yang juga merangkap tugas pengurusan dokumen kayu bukan hanya terjadi di Ciamis, tetapi sudah menjadi rahasia umum karena peran dan fungsi penyuluh yang dimarjinalkan dalam era otonomi daerah. Trend seperti ini harus segera dicarikan jalan keluarnya sebagai upaya meluruskan kembali paradigma penyuluh sebagai aparatur yang tugasnya membantu mensejahterakan masyarakat bukan mensejahterakan pihakpihak lainnya.

Tanpa solusi yang cepat dan tepat atas peran ganda dari penyuluh tersebut, maka pemberdayaan masyarakat dan pengentasan kemiskinan (SK Menhut No. SK. 132/Menhut-II/2004 tentang Pedoman Umum Penyuluhan Kehutanan) hanya retorika 
belaka yang tidak akan pernah terwujud.

\section{Pengurusan dokumen kayu berbiaya tinggi}

Ada keluhan dari beberapa pengusaha kayu bahwa pengurusan dokumen SKAUK dan SKSHH seringkali menimbulkan ekonomi biaya tinggi (bigh cost economy) bagi bisnis yang dikelola mereka. Harapan pengusaha kayu agar proses pengurusan dokumen kayunya dimudahkan dan dimurahkan atau paling tidak besaran "biaya administrasi" nya dikurangi atau dikompensasikan ke dalam penerimaan daerah (PAD) kabupaten Ciamis.

Biaya tinggi pengurusan dokumen SKAUK dan SKSHH dimungkinkan karena dualisme pengurusan antara Sentra Industri dan Dinas Kehutanan serta keterbatasan jumlah personil dan lokasi pelayanan, dimana kantor pelayanan (UPTD) Dinas Kehutanan tersebar tidak merata. Sebagai contoh UPTD wilayah I Kawali melayani 22 kecamatan, sementara UPTD Wilayah III Cijulang melayani hanya 3 (tiga) kecamatan sebagaimana tercantum dalam Tabel 1.

Keterbatasan personil dan luasnya cakupan wilayah akan membuka peluang terjadinya "negosiasi" dalam pemberian pelayanannya, sehingga hal ini perlu menjadi bahan pertimbangan untuk mengatur kembali fungsi dan kedudukan kantor UPTD tersebut.

\section{Tabe 1. Wilayah pelayanan UPTD Dinas Kehutanan Ciamis tahun 2005} Table 1. Service area of UPTD of Ciamis Forestry Service in year 2005

\begin{tabular}{|c|l|c|l|}
\hline No. & $\begin{array}{c}\text { Wilayah UPTD } \\
\text { (Service area of } \\
\text { UPTD) }\end{array}$ & $\begin{array}{c}\text { Cakupan Wilayah } \\
\text { Kecamatan } \\
\text { (Covering of Sub- } \\
\text { district Area), } \\
\text { unit }\end{array}$ & $\begin{array}{c}\text { Lokasi Sementara Kedudukan } \\
\text { Kantor UPTD } \\
\text { (Tentaive location of UPTD } \\
\text { offices) }\end{array}$ \\
\hline 1. & Wilayah I Kawali & 22 & Desa Saguling, Kecamatan Baregbeg \\
\hline 2. & Wilayah II Banjarsari & 7 & Desa Kertaharja, Kecamatan Pamarican \\
\hline 3. & Wilayah III Cijulang & 3 & Kantor Camat Cijulang \\
\hline 4. & $\begin{array}{l}\text { Wilayah IV } \\
\text { Pangandaran }\end{array}$ & 4 & Kantor BPP, Kecamatan Pangandaran \\
\hline & Jumlah & 36 & \\
\hline
\end{tabular}

Sumber (Source): Dinas Kehutanan Ciamis (2006a).

Berkaitan dengan ekonomi biaya tinggi pengurusan dokumen kayu tidak hanya terjadi di Kabupaten Ciamis, tetapi hampir di setiap kabupaten sehingga hal ini perlu menjadi perhatian Dinas Kehutanan Ciamis karena dalam Perda 19/2004 Pasal 5 dinyatakan bahwa perorangan/badan usaha yang telah mendapatkan SKAUK dan pengesahan Kepala Dinas diwajibkan hanya mengganti biaya cetak leges sesuai dengan ketentuan yang berlaku (Rp 3.000).

Disamping itu, penerbitan SKSHH seharusnya bebas biaya karena biaya pencetakannya sekitar Rp 18 milyar sudah ditanggung Departemen Kehutanan, namun di 
Luar Pulau Jawa selembar SKSHH dapat berharga jutaan rupiah untuk mendukung kelancaran pelaksanaan penebangan liar dan peredarannya (illegal logging and trading) (Soebiato, 2005). Walaupun SKSHH bebas biaya, namun disisi lain tidak disediakan biaya operasional untuk implementasinya sehingga seringkali institusi kehutanan memunculkan "biaya administrasi" yang berbeda-beda untuk masing-masing daerah.

Sudah bertahun-tahun hal ini terus terjadi, sebagaimana telah dilaporkan oleh Subarudi (1984) tentang manipulasi SAKO/B di lapangan dari mulai (I) penggunaan $\mathrm{SAKO} / \mathrm{B}$ aspal (asli tapi palsu), (ii) pengunaan $\mathrm{SAKO} / \mathrm{B}$ yang didaur ulang, (iii) penghapusan tanda "sudah tidak berlaku lagi" pada dokumen kayu, (iv) tidak pernah dilakukan cek fisik di lapangan, (v) Petugas Pengawasan Kayu Bulat (P2KB) yang "main mata" dengan pengusaha. Namun tindak lanjut yang dilakukan oleh Departemen Kehutanan hanya berupa ganti nama dari SAKO/SAKB menjadi SKSHH, tanpa menyentuh akar permasalahannya sehingga kasus-kasus penyalahgunaan dokumen tersebut akan terus berulang dan muncul kembali sepanjang tahun.

Dalam pengamatan penulis ternyata tidak ada korelasi nyata dan langsung antara jumlah SKSHH yang diterbitkan dengan kebijakan pemerintah dalam pembatasan jatah tebangan. Pembatasan jumlah tebangan tidak diikuti dengan pembatasan penerbitan SKSHH sehingga wajar saja jika program pemberantasan illegal logging kurang berhasil dan dipandang hanya retorika belaka atas ketidak mampuan institusi yang mengurusi sumber daya hutan.

\section{Marjinalisasi peran dan fungsi desa}

Dalam hal ini kepala/aparat desa sering kali tidak melakukan pengecekan fisik di lapangan dan hanya menandatangani dokumen SKAUK di atas meja. Walaupun ada sebagian aparat desa yang melakukan pengecekan fisik di lapangan, namun jumlahnya relatif kecil dibandingkan dengan aparat desa yang tidak melakukan pengecekan fisik. Hal ini dapat dimaklumi karena hampir semua aparat desa belum dilatih bagaimana mentaksasi kayu dan mengecek kebenaran lokasi kayu yang akan ditebang.

Dalam pelaksanaan penebangan, kadangkala mereka (pedagang pengumpul) sudah melaksanakan penebangan tanpa mengantongi SKAUK atau kegiatan penebangan dilakukan bersamaan dengan pengurusan SKAUK sehingga pengurusan SKAUK selesai, kegiatan penebangannya juga telah selesai.

Dalam kegiatan penanaman kembali pada areal yang telah ditebang sangat sulit untuk dipantau atau dapat dikatakan tidak secara otomatis dilaksanakan karena jangan pun mereka mau melaksanakan penanaman sendiri karena bagi petani mencari bibit saja sudah demikian sulit. Kegiatan penanaman kemungkinan besar hanya menunggu pembagian bibit gratis dari Dinas Kehutanan melalui proyek Gerhan dan GRLK.

\section{Pembinaan dan pengawasan TUK belum berjalan}

Persoalan implementasi kebijakan merupakan masalah manajemen dan bukan lagi perkara kebijakan. Selama ini persoalan kerap dianggap sudah teratasi jika peraturan telah diumumkan. Padahal, bersama penyusunan kebijakan perlu diperjelas pula aturan teknik pelaksanaannya serta bagaimana pelaksanaan tersebut dimonitor. Pergantian orang pada sejumlah posisi serta mekanisme pemberian sanksi dan penghargaan tidak bisa 


\section{J umal AnalisisKedijakanKehutanan Vd. 3No. 2, J uni 2006: 109- 123}

dihindarkan bila manajemen pemerintahan memang ingin dibenahi (Hidayati dan Suruji, 2006).

Dari kenyataan di atas, maka dinas kehutanan sekali lagi harus memperbaiki sistem administrasi dan penerapan sanksi/hukuman bagi aparaturnya yang tidak melaksanakan tugas sebagaimana mestinya dan penghargaan kepada aparaturnya yang sudah bekerja dengan baik dan memberikan kontribusi besar terhadap pencapaian visi dan misi Dinas Kehutanan Ciamis.

\section{Rumusan Kebijakan TUKyang Tepat}

Ada beberapa aspek yang perlu dilakukan sebagai upaya untuk membuat rumusan kebijakan TUK yang tepat dan sesuai dengan kondisi di lapangan, diantaranya: (i) penyamaan persepsi tentang SKSHH, (ii) sistem TUK sesuai dengan asal usul hutan, (iii) sistem TUK yang mudah dan murah, dan (iv) revitalisasi peran dan fungsi penyuluh.

\section{Penyamaan persepsi tentang SKSHH}

Penyamaan persepsi tentang SKSHH oleh para pihak sangat diperlukan karena dalam kenyataannya di lapangan banyak menimbulkan salah kaprah dalam pemanfaatannya yang sangat tergantung kepada kepentingan masing-masing pihak tersebut.

SKSHH adalah dokumen resmi yang diterbitkan oleh pejabat yang berwenang dan digunakan dalam pengangkutan, penguasaan dan pemilikan hasil hutan, sebagai alat bukti atas legalitas hasil hutan. SKSHH inilah yang dijadikan dokumen yang sah dalam kegiatan pengangkut atau peredaran kayu bulat/kayu olahan sehingga kayu tanpa dokumen tersebut dapat dianggap sebagai hasil penebangan atau perdagangan liar.

SKSHH ini diberlakukan sejak tahun 2000 sebagai pengganti SAKB (Surat Angkutan Kayu Bulat) dan SAKO (Surat Angkutan Kayu Olahan). Pencetus atau penggagas tentang pergantian dan pilihan nama dari SAKO/B menjadi SKSHH patut mendapat penghargaan karena telah berhasil membuat para pihak yakin bahwa membawa kayu apapun tanpa SKSHH dianggap tidak sah atau illegal sesuai dengan kepanjangan kata SKSHH.

Sebenarnya SKSHH itu bukan merupakan satu-satunya dokumen yang sah untuk mengangkut kayu karena secara prinsip dokumen SKSHH merupakan alat bukti (administrasi) bahwa kayu yang dibawanya berasal dari sumber yang legal dan dapat dipertanggung jawabkan kebenaran asal usulnya.

Sebagai ilustrasi dapat digambarkan bahwa jika seorang membeli sebuah televisi (TV), maka oleh toko penjual TV akan diberikan sebuah alat bukti (kwitansi) atau faktur pembelian yang isinya berupa: (i) nama toko penjual, (ii) nama dan alamat si pembeli, (iii) spesifikasi barang yang dibelinya, dan (iv) harga yang dibayarkannya. Kwitansi tersebut menjadi alat bukti kepemilikan bahwa TV yang dibawa telah menjadi milik si pembeli dan dapat pula dijadikan sebagai surat jalan jika ada pemeriksaan di jalanan oleh pihak yang berwajib.

Jadi secara prinsip SKSHH sama dengan faktur pembelian TV tersebut sehingga jika ada pemeriksaan fisik angkutan di jalan, si pengemudi cukup dengan menunjukkan 
atau memberikan faktur tersebut kepada pihak yang berwenang dan setelah diteliti ke aslian faktur tersebut, maka si pengemudi diijinkan untuk melanjutkan perjalannya mengangkut TV tersebut.

Namun dalam perjalanan waktu, pihak yang berwajib kadang bersikukuh bahwa semua kayu tanpa SKSHH dianggap tidak sah karena memang nama dokumennya surat keterangan sahnya hasil hutan, jadi dokumen selain SKSHH dianggap melanggar dan menyalahi peraturan dan tidak sah. Hal ini seringkali menjadi kontraproduktif terhadap perkembangan hutan rakyat di daerah.

\section{Sistem TUK sesuai dengan asal usul hutan}

Subarudi (2004) menegaskan bahwa sistem TUK yang berlaku secara nasional harus dibedakan menjadi 3 (tiga) sistem TUK, antara lain (i) sistem TUK hutan alam, (ii) sisten TUK hutan tanaman, dan (iii) sistem TUK hutan rakyat/kemasyarakatan.

Bagi TUK hutan alam karena menyangkut asset negara berupa pembayaran nilai tegakan hutan alam, maka sangat perlu digunakan SKSHH dalam upaya memonitor jumlah kayu dari hutan alam yang ditebang dan kemana saja peredaran kayu tersebut dilakukan.

TUK hutan tanaman harus berbeda dengan TUK hutan alam karena kayu yang ditebang dan diedarkan merupakan hasil kegiatan penanaman oleh suatu perusahaan. Dalam kasus ini hendaknya perlu digunakan faktur pembelian atau surat angkut khusus (bukan SKSHH) yang menyatakan bahwa kayu tersebut diambil dari perusahaan X dan akan dibawa ke perusahaan kayu Y.

TUK hutan rakyat juga harus berbeda TUK hutan tanaman walaupun kayunya sama-sama berasal dari kegiatan penanaman. Kayu yang berasal dari hutan rakyat (HR) dan hutan kemasyarakatan (HKm) hanya perlu surat keterangan asal usul kayu (SKAUK) yang menunjukkan bahwa kayu yang ditebang dan diedarkan berasal dari lahan milik si pulan. SKAUK ini harus diberikan oleh kepala dusun dan diketahui oleh kepala desa untuk menghindari konflik sosial diantara warga jika pohon yang ditebang bukan berada di lahannya melainkan milik tetangganya.

Kabupaten Ciamis telah terlebih dahulu (pertama di Indonesia) memiliki sistem TUK hutan rakyat yang menggunakan SKAUK sebagaimana tercantum dalam Perda No. 19/2004 yang dirasakan sudah ideal, namun dalam pelaksanaannya masih banyak kendala di lapangan sehingga perlu diperbaiki agar tidak menjadi disinsentif dan kontraproduktif bagi para petani dan pengusaha kayu yang ada di Ciamis.

Permenhut No. 51 Tahun 2006 tentang penggunaan surat keterangan asal usul (SKAU) untuk pengangkutan hasil hutan kayu yang berasal dari hutan hak telah mendukung penggunaan SKAU, tetapi belum mencantumkan sanksi hukum jika kepala desa melakukan penyimpangan dalam melaksanakan tugasnya karena peran kepala desa sebagai penerbit SKAU dianggap rawan penyimpangan dan menyuburkan peredaran kayu illegal.

\section{Sistem TUK yang murah dan mudah}

Sebenarnya ada upaya untuk mengganti biaya tinggi dalam sistem TUK dengan menerapkan eko-ekonomi, dimana harga kayu yang layak ditetapkan berdasarkan harga 


\section{J umal AnalisisKedijakanKehutanan Vd. 3No. 2, J uni 2006: 109- 123}

kayu tersebut ditambah dengan "pajak" lingkungan akibat penebangan pohon sehingga biaya tambahan dari kayu tersebut dapat dimanfaatkan kembali oleh institusi kehutanan untuk menanam pohon dan menutup biaya transaksi tersebut.

Penetapan pajak lingkungan ini sejalan dengan pernyataan Mutis (2006) bahwa merestrukturisasi biaya dengan meningkatkan pajak atas kayu tebangan akan merefleksikan biaya perlindungan kepada masyarakat. Sebagai contoh bila kita membeli selembar papan dari sebuah perusahaan kayu, sebenarnya kita hanya membayar harga kayu plus harga konversi dari kayu ke papan, namun cenderung mengabaikan upaya konservasi dan kesinambungan daya dukung alam.

Disamping itu keberadaan unit Sentra Industri (yang mengurusi dokumen kayu olahan) di Kabupaten Ciamis sudah tidak diperlukan lagi dan harus dihapuskan sebagai upaya memudahkan dan memurahkan sistem TUK serta meningkatkan sistem informasi manajemen TUK itu sendiri.

Oleh karena itu, perubahan kebijakan seharusnya dapat mencontoh perubahan manajemen restoran. Mereka tidak lagi sekedar membenahi manajemen menu yang dibikin dan disajikan restoran tetapi sudah melangkah jauh dan maju, bagaimana mengantar sajian makanan dapat sampai secepatnya ke rumah konsumen dalam keadaan masih hangat dan sedap (Hidayati dan Suruji, 2006). Dalam hal ini pemerintah pusat dan daerah harus pro aktif melakukan perubahan kebijakan yang sesuai dengan tuntutan masyarakat dalam koridor perubahan yang jelas dan terencana dengan baik.

\section{Revitalisasi peran dan fungsi penyuluh}

Sebagaimana telah dijelaskan dalam uraian desa sebagai unit pengelolaan hutan rakyat lestari (UPHRL), maka peran dan fungsi penyuluh dapat lebih ditingkatkan karena selama ini peran dan fungsi mereka telah dipinggirkan oleh pemerintah daerah di era otonomi daerah dan hanya dipandang sebagai pusat pengeluaran (cost center). Apalagi saat ini sebagian besar penyuluh-penyuluh kehutanan di daerah sudah memasuki usia pensiun sehingga perlu biaya yang cukup banyak untuk merekrut tenaga penyuluh yang baru (Subarudi, 2006).

Subarudi (2001) menegaskan bahwa kasus-kasus konflik kehutanan di daerah tidak terlepas dari peran dan fungsi penyuluh yang mandul serta ketidak siapan pemerintah pusat dalam merespon otonomi daerah dalam pengelolaan hutan. Kemandulan peran dan fungsi penyuluh lebih disebabkan karena masalah institusi tempat penyuluh berkarya, sarana dan prasarana kerja yang tidak mendukung tugas pokok dan fungsinya serta rendahnya keterampilan penyuluh.

Hasil wawancara terhadap penyuluh kehutanan di beberapa Kabupaten mengatakan mereka merasa ditelantarkan setelah otonomi daerah dan mereka telah putus hubungan sama sekali dengan Pusat Penyuluhan Kehutanan, Departemen Kehutanan.

Di beberapa daerah kabupaten baik di P. Jawa dan luar P. Jawa, ada penyuluhpenyuluh kehutanan telah beralih kedudukan sebagai oknum perantara jual-beli SKSHH sehingga menambah marak kasus-kasus penebangan liar. Oleh karena itu Departemen perlu juga mencari bagaimana mekanisme hubungan kelembagaan yang tepat antara Pusat Pembinaan Penyuluhan Kehutanan dengan DKK yang terkait dengan pembinaan dan pengembangan tenaga penyuluh di wilayah kabupaten. 
Permasalahan besar yang hingga kini belum disepakati adalah penentuan siapa masyarakat sasaran untuk kegiatan penyuluhan kehutanan. Subiyanto (2001) secara kritis telah membahas tentang siapa sebenarnya sasaran dari kegiatan penyuluhan dan menyimpulkan bahwa sasaran utama penyuluh yaitu petani (cocok tanam) di hutan adalah tidak relevan karena prosentasenya yang kecil $(10 \%)$ dan yang terbesar adalah pengusaha HPH, HPHTI, dan HPHH (60\%), dan industri kehutanan $(30 \%)$.

Pemerintah Daerah Tasikmalaya telah merespon kelemahan sistem kelembagaan penyuluh dengan membentuk Kantor Pusat Penyuluh (KPP) sebagai wadah yang menampung semua penyuluh-penyuluh antar sektor seperti Pertanian, Keluarga Berencana, Perikanan, dan Kesehatan. Kelebihan dari pembentukan KPP ini adalah keterpaduan, efisiensi dan efektifitas suatu kegiatan penyuluhan di wilayah tertentu, namun ego sektoral masih sulit untuk dihindari dalam pelaksanaan penyuluhan terpadu tersebut. Hal ini perlu menjadi perhatian dalam penerapan UU Penyuluhan Terpadu yang menurut informasi sudah disetujui DPR dan tinggal ditandatangani oleh Presiden.

Peran dan fungsi penyuluh ke depan adalah membantu desa dalam kegiatan perencanaan hutan rakyat yang bekerjasama dengan aparat desa terkait untuk mengumpulkan data dan informasi tentang luasan, kepemilikan, dan jenis tanaman kehutanan serta pola budidaya yang berada dalam lokasi hutan rakyat sehingga desa nantinya dapat menjadi unit pengelolaan hutan rakyat lestari (UPHRL).

\section{KESIMPULAN DAN SARAN}

\section{A. Kesimpulan}

Kabupaten Ciamis dengan produksi kayu bulat hutan rakyatnya tahun 2005 mencapai $325.000 \mathrm{~m}^{3}$ merupakan kabupaten dengan produksi kayu rakyat terbesar di provinsi Jawa Barat. Produksi kayu rakyat tersebut masih dibawah kebutuhan rill untuk industri penggergajian.

Analisis pasokan dan kebutuhan kayu bulat di kabupaten Ciamis menunjukkan bahwa kebutuhan yang ada $\left(0,75-1,12\right.$ juta $\left.\mathrm{m}^{3}\right)$ sudah melebihi pasokan resmi yang tercatat $\left(325.000 \mathrm{~m}^{3}\right)$. Hal ini ditandai dengan kehadiran sekitar 426 unit industri penggergajian (sawmills) dengan kapasitas produksi sekitar $900-2.500 \mathrm{~m}^{3}$ per tahun per unit.

Sistem TUK hutan rakyat yang berlaku di Ciamis (Perda No. 19/2004) sudah cukup ideal secara konseptual, namun masih banyak permasalahan dan penyimpangan dalam tataran penerapannya di lapangan yang meliputi: (i) PKL yang masih berperan ganda sebagai perantara pengurusan dokumen kayu daripada juru penerang bagi petani hutan rakyat, (ii) pengecekan fisik pohon/tegakan yang akan ditebang tidak dilakukan sebagaimana mestinya, (iii) kepala desa seringkali menandatangani SKAUK tanpa melakukan pengecekan lapangan terlebih dahulu, (iv) pengusaha kayu mengeluh tentang biaya tinggi (bigh costeconomy) dalam pengurusan dokumen SKAUK dan SKSHH.

Penyempurnaan sistem TUK hutan rakyat dapat dilakukan melalui berbagai langkah, diantaranya: (i) penyamaan persepsi tentang SKSHH, (ii) sistem TUK sesuai dengan asal usul kayu, (iii) sistem TUK yang mudah dan murah, dan (iv) revitalisasi peran dan fungsi penyuluh.

Perumusan dan penyempurnaan TUK hutan rakyat di Ciamis hendaknya 


\section{J umal AnalisisKedijakanKehutanan Vd. 3No. 2, J uni 2006: 109- 123}

dilakukan setelah dilakukan evaluasi yang menyeluruh terhadap substansi, pelaksanaannya, dan tidak hanya sekedar ganti Perda, tetapi harus melibatkan para pihak (partisipatif), dilakukan segera mungkin (tepat waktu), dapat mencegah penyimpangan di lapangan (aturan main dan sanksi yang tegas), serta sesuai dengan harapan pelaku usaha (mengakomodir pengguna kebijakan).

Jumlah dan kehadiran UPTD masih menjadi kendala terutama berkaitan dengan tupoksinya yang hanya mengurus dokumen dan peredaran kayu, padahal dapat lebih diperluas tupoksinya dengan melakukan kegiatan dari mulai perencanaan hingga pasca panen sehingga kehadiran UPTD sangat dirasakan manfaatnya tidak saja oleh pengusaha kayu, tetapi juga petani hutan rakyat yang terkait.

\section{B. Saran}

Departemen Kehutanan, Dinas Kehutanan Provinsi, dan Dinas Kehutanan Kabupaten dapat duduk bersama dan merancang dan merumuskan sistem TUK hutan rakyat yang sederhana, mudah, dan murah sehingga akan menjadi insentif nyata bagi perkembangan hutan rakyat di seluruh nusantara.

Melihat jumlah dan sebaran UPTD yang tidak merata, maka Dinas Kehutanan Ciamis harus meninjau ulang keberadaan UPTD nya disesuaikan dengan potensi hutan rakyat di masing-masing kecamatan daripada hanya berdasarkan wilayah administrasi kecamatan semata.

\section{DAFTAR PUSTAKA}

Danim, S. 2000. Pengantar Studi Penelitian Kebijakan. Cetakan Kedua. Penerbit PT. Bumi Aksara, Jakarta

Dishut Ciamis. 2004. Perda Kabupaten Ciamis Nomor 19 Tahun 2004 tentang

Dishut Ciamis. 2005. Laporan Akuntabilitas Kinerja Tahun 2004. Dinas Kehutanan Kabupaten Ciamis.

Dishut Ciamis. 2006a. Laporan Akuntabilitas Kinerja Tahun 2006. Dinas Kehutanan Kabupaten Ciamis.

Dishut Ciamis. 2006b. Daftar Isian Penggunanan Anggaran (DIPA) Tahun 2006. Dinas Kehutanan Kabupaten Ciamis.

Hidayati, N., dan Suruji, A. 2006. Perekonomian: Benahi Manajemen Pengantaran Produk. Harian Kompas, tanggal 7 Juli 2006.

Keputusan Bupati Ciamis Nomor 185.A Tahun 2004 tentang Petunjuk Pelaksanaan Perda Kabupaten Ciamis Nomor 19 Tahun 2004 tentang Produksi dan Peredaran Kayu Rakyat.

Kompas. 2006. Potensi Hutan Rakyat Menjanjikan. Harian Kompas, tanggal 7 Juli 2006. 
Mutis, T. 2006. "The Ecological Truth”, Ekonomi dan Koperasi. Harian Kompas, tanggal 14 Juli 2006.

Perda Kabupaten Ciamis Nomor 19 Tahun 2004 tentang Produksi dan Peredaran Kayu Rakyat.

Produksi dan Peredaran Kayu Rakyat.

Seputar Indonesia. 2006. Ratusan Perusahaan Tanpa Ijin Ditertibkan. Harian Seputar Indonesia, tanggal 14 Juni 2006.

Soebiato, P. 2005. Perjalanan Akhir Dokumen SKSHH di Kehutanan. Majalah Surili Vol. 35/No.2/Juni 2005.

Subarudi. 1984. Studi Kasus Penebangan Liar. Harian Manuntung, Samarinda, Kalimantan Timur, tanggal 18 September 1984.

2001. Penyelesaian Konflik Kehutanan Di daerah: suatu Kebutuhan yang Mendesak. Silvatropika No. 19/2001, Badan Litbang Kehutanan, Jakarta.

. 2004. Bahan Diskusi Sistem Tata Usaha Kayu. Rapat Internal Badan Litbang, tanggal 27 Juli 2004, di Jakarta. (Tidak diterbitkan).

. 2006. Desa sebagai Unit Pengelolaan Hutan Rakyat Lestari (UPHRL). Buletin Perencanaan Badan Planologi Kehutanan No. 3 Tahun 2006. Badan Planologi Kehutanan, Jakarta.

Subiayanto, B.S. 2001. Pengembangan Penyelenggaraan Penyuluhan Kehutanan Oleh Dunia Usaha Kehutanan Agar Penyuluhan Lebih Efektif dan Efisien. Makalah disampaikan pada Seminar Pengembangan Penyuluhan Kehutanan Nasional, Di Jakarta, 5 - 6 Desember 2001. 